\title{
Vildsvinet som spelar luta. Om konstiga djur i medeltida ballader
}

\section{Av Tommy Olofsson}

"Skal jag min mödom mista,/ så skal war gafwel i sängen brista”. Det är offensiva sexuella krav. Den som artikulerar dem är flugan i skämtballaden "Tordyvelns bröllop", ${ }^{1}$ som är en alldeles underbar parodi på riddarvisans bröllopsmotiv och ståndshögfärd. Den brudgum som ska driva flugan till passionens sängsprängande höjder är vanligtvis en tordyvel, i några versioner en broms. Det parodiska anslaget är uppenbart, till exempel i denna inledningsstrof:

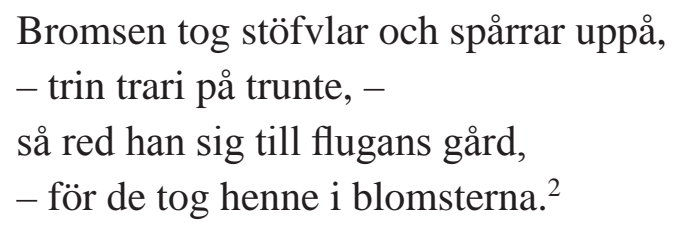

De tog henne "i blomsterna", kanske rentav i den ständigt amorösa rosenlunden. I vissa versioner är bromsen snarast ett slags äktenskapsmäklare och tordyveln den brudgum som ska lyckliggöra den trånfullt krävande flugan på bröllopsnatten. Rollerna växlar. Växlar gör också flugans attityd. Oftast är hon sexglad och passionerat förväntansfull, detta i enlighet med den medeltida föreställningen att kvinnans könsdrift är starkare än mannens, ${ }^{3}$ men det händer också att hon är förnämt högfärdig och inte vill gifta sig med vare sig tordyveln eller bromsen. ${ }^{4}$ Det finns visserligen gulliga varianter av denna ballad, men även dessa är satiriskt riktade mot högreståndsbröllop och parodiska gentemot riddarvisans höviska erotiska later. Det är utan tvivel en ballad som hämtar sin komiska energi från de kontraster som etableras gentemot den höviska kärlekens upphöjda sociala koreografi:
Nu börja alla att hoppa,
brudgummen dansa med en loppa.
$\AA ̊$ dansen gick till dag vart ljus,
å bruden dansa med en väggelus.
De blev ett bröllop som var stort, de stod allt ut i en hästelort. ${ }^{5}$

\footnotetext{
1 SMB 253 Ba. När jag här och framgent hänvisar till SMB syftar jag på Sveriges medeltida ballader, band 5, vol. 1-2, red. Sven-Bertil Jansson och Margareta Jersild, Stockholm 2001.

2 Ibid.

3 Tanken att mannens könsdrift är starkare än kvinnans är en nymodighet och uppkom först i och med romantikens genombrott i slutet av 1700-talet.

4 Mest explicit i SMB 253 Ea.

5 SMB $253 \mathrm{~N}$.
} 
En med "Tordyvelns bröllop” nära besläktad parodi på ett ståndsmässigt bröllop är balladen "Bröllopet i Kråkelund", med en mängd av djur som komiskt groteska figuranter. Här är det verkligen fest i fablernas värld. En av de lustigaste passagerna handlar om en av servitrisernas bråda bestyr med att servera mjöd och vin. Servitrisen är en skata. Olämpligt långa stjärtfjädrar försvårar hennes rörelser mellan borden. Hur hon än vänder och vrider sig, hinner hon inte hälla upp tillräckligt med mjöd och vin till de strupar som längtar så mycket, har så ”mykijtt thrang”:

Skatan skännker Både Miöö och wijn

thär war så mykijtt thrang

hun får sijg hwarken Rööra Eller wändt

thy Rumpen war henne för långh

- Wllffwen dricker aff Syllfwer skåål J Skoogen ${ }^{6}$

Även döden och de konventioner som är förknippade med den parodieras i en ballad med djurmotiv. Det är ett ännu djärvare grepp än att parodiera ett höviskt bröllop. I "Kattens död" skildras hur en katt ligger på sitt yttersta och snart drar sin sista suck. I flera versioner är katten skildrad som en person från överklassen, omgiven av sitt motvilliga tjänstefolk av lägre social rang, nämligen råttor och möss. När katten blir sjuk kommer en hemhjälp fort springande:

Då kom en råtta framspringande

hon både buga och niga

Behagar er någon farske stek

min lilla kattefruga

- För nu är lille-katta sjuker

Katten är inte sugen på någon färsk stek utan känner sig så illa däran att hon föredrar att råttan omgående går och hämtar en präst. Råttan ger sig åstad, ordnar en snickare som gör en kista till katten, en prästfru som förfärdigar en svepning och en präst som kommer för att begrava ”lille-katta”. Behjälpliga vid gravsättningen är en skara möss:

Och fyra voro de stora möss

som under bårena gingo

Och åtta voro de snälla små

som både grävde och ringde. ${ }^{7}$

Nästan lika respektlös som ”Kattens död” är den ballad som heter ”Rävens testamente”, som också den skojar med döden. Den som kommer till tals i balladen är en listig räv, som har slukat en gässling, medan bonden har varit endera på gille eller mässa. När bonden kommer hem, hittar han inte sin gässling och frågar räven, som genast bekänner:

Gås-ungen var båd fager och fin

Han rann så lätt i halsen på mig. ${ }^{8}$

6 SMB 254 A.

7 SMB $252 \mathrm{~L}$.

8 SMB 250 A. 
Bonden blir ursinnig och gör sig redo att hämnas:

Har du ätit upp gås-ungen min

så skall jag kläd’ af dig ditt ludna skinn.

Det är i denna prekära belägenhet som räven visar sig vara listig. Han ber inte om nåd, väl medveten om att en sådan bön skulle vara utsiktslös. Däremot begär han en stunds respit för att hinna upprätta sitt testamente. Det är en begäran som den fromme bonden i sin rättskaffenhet inte kan avslå. Och så sjunger räven ut med sitt ganska utförliga testamente, som så till den grad tycks förvåna bonden att denne slappnar av i sin vaksamhet tillräckligt mycket för att räven ska kunna komma undan och smita till skogs:

Käre Bonde du låt mig få lefva medan jag får mitt testament göra.

Alla tingsmännen ger jag mina öron för de ska så mycket dåligt vid tingsrätten föra.

Alla käringar ger jag mina tänder, för de äro bara, de gå aldrig sönder.

Alla pigor ger jag mina ben för de ska va snara och aldrig sen.

Alla skyttar ger jag min rumpa för de ska i skogen efter mig skumpa.

Så slog han en sling slang på rumpan sin

Så sprang han sig åt skogen in.

- Si’st du, jag lurade bonden. ${ }^{9}$

Ännu färgstarkare utlägger räven sitt testamente i en annan version av samma ballad:

Qvinjorna i lunden gifver ja mitt röda skinj

Får di ska alltid vara svifta omkrinj.

Dränjena i lunden gifver ja min långa rompa

Får di ska alltid stå på loen å bompa

Piorna i lunden gifver ja mina svartbruna ögen

Får di ska alltid på dränjana tita.

Pågarna i lunden gifver ja mina svårte lopper

Får di ska alltid uppå horsena hoppa

Töserna i lunden gifver ja min lilla tunga

Får di ska alltid för di små barnena sjunga ${ }^{10}$

En mental kraftmätning mellan bonde och räv utspelas även i en annan ballad, ”Bonden och räven”, denna gång med helt annat resultat, för nu är det bonden som överlistar

9 SMB $250 \mathrm{~A}$.

10 SMB $250 \mathrm{~B}$. 
räven och skjuter honom, i vissa versioner även hans syster, kallad "Räfvesan” eller "Räfvatikan”. Bonden är listig, lögnaktig och grym. Mellan honom och räven utspelas en ordduell, som tar sin början i en köpslagan. Bonden säger sig vilja köpa rävens skinn, som han önskar få till "foder under lufvan min", och är beredd att betala bra, men räven riposterar fyndigt bondens alla anbud. Så här kan det låta:

En väl gödder Oxe vill jag gifva dig den bästa som du vill hafva

- $\quad$ bara jag får huden din

till foder under luvan min

till Julen

En väl gödder Oxe vill jag intet ha

för den kan jag intet slackta

- $\quad$ aldrig får du huden min

till foder under luvan din

till Julen

Ett gångande skepp det vill jag gifva dig

det bästa som du vill hafva

Ett gångande skepp det vill jag intet ha

ty det kan jag intet styra

En väl gödder Gris den vill jag gifva dig

den bästa som du vill äta

En väl gödder Gris vill jag intet ha

för den kan jag intet äta

En väl gödder Gås det vill jag gifva dig

den bästa som du vill hafva

En väl gödder gås är väl god att ha

men huden är svår att mista ${ }^{11}$

Och så vidare! Räven är alltså klokt nog rädd om sitt skinn och vill ogärna sälja det i utbyte mot någon av alla de godsaker som bonden erbjuder. I andra versioner är det inte i första hand god mat som bonden erbjuder utan exempelvis "ett förgyllande svärd” eller "en gångare grå" (en häst). I själva ordduellen står sig räven gott och ger lämpligt mothugg på varje erbjudande från bonden. Ändå slutar balladen i bråd död för räven. Katastrofen inträffar när hans syster, ”Räfvatikan” (rävtiken), näsvist hoppar ut ur lyan och lägger sig i köpslåendet, endera genom att säga till sin bror vad han redan vet, att han förstås inte ska sälja sitt skinn till något pris i världen, eller genom att läxa upp bonden för att han är så dum att han tror att han kan lura en räv. I detta ögonblick av tillfällig förvirring slår bonden blixtsnabbt till och skjuter räven med sin pil, i de flesta fall även

11 SMB 251 Aa. 
den olycksaliga "Räfvinnan”, ”Räfvatikan” eller ”Räfvesan”. Och så får bonden skinn till luvan sin till julen.

Det finns fler ballader med förmänskligade sagodjur. Bland skämtballaderna utgör de en särskild grupp, urskiljbar från de övriga just genom sina djurmotiv, dock inte beträffande tematiken. Den senare behandlar, som synes, bröllop och död och lurendrejeri, just sådant som även vanliga ballader med människor ofta kretsar kring.

Aisopos fabler var väl kända under medeltiden och ingick i de muntligt förmedlade visdomsorden. Det händer också att några av dem avbildas i kyrkorna och i medeltida skrifter, ${ }^{12}$ men ett djurmotiv som inte har hämtats från Aisopos utan från ett gammalt ordspråk av okänt ursprung är ”Den predikande räven”. Kerstin Rodin har skrivit en hel avhandling om detta motiv, Räven predikar för Gässen, ${ }^{13}$ och visar i sin djuplodande framställning hur oerhört spritt detta motiv var i Europa under senmedeltiden, möjligen som ett förebud om vad som skulle komma, nämligen reformationen. Räven som predikar för gässen är ett motiv som kan tolkas på många sätt, visar Rodin i sin bok. Vad som intresserar oss i detta sammanhang är den bild av räven som vanligtvis framkallas i dessa bilder, en slug, listig, falsk och ondskefull figur och som sådan "en symbol för det onda - de religiösa hycklarna, kättarna och djävulen”. ${ }^{14}$ Nordens i våra ögon mest uttrycksfulla kalkmålning av detta motiv finns i Ottestrups kyrka på västra Sjælland. Så här ser det där ut när räven predikar för gässen, medan hans kumpan springer fram och roffar åt sig av de intet ont anande godbitarna.

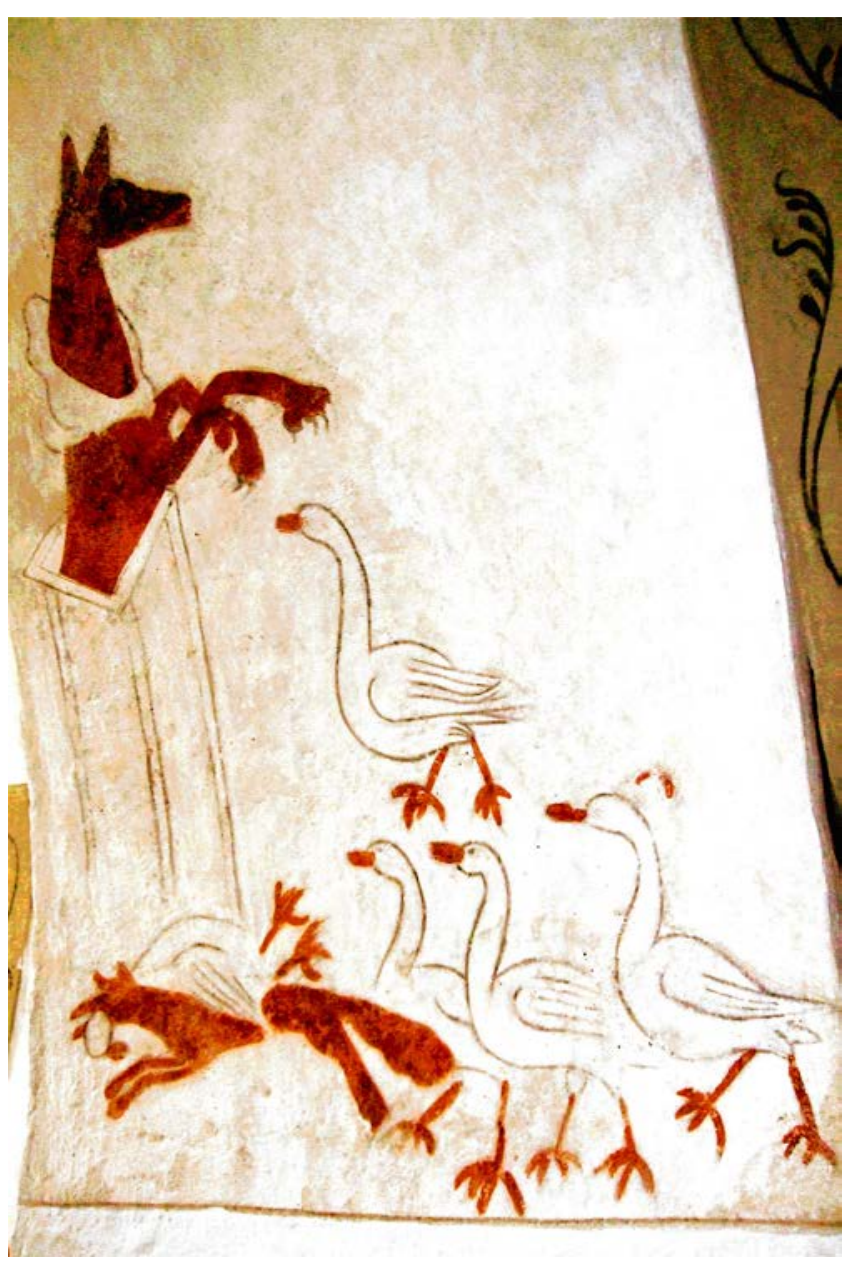

Som bekant är dessa oskuldsfulla gäss i själva verket inte dummare än att de med gemensam förslagenhet senare kan lura rävarna i en fälla och straffa dem. Ondskan får

12 Exempelvis i en illuminerad handskrift från 1436-1437 som återger Magnus Erikssons landslag. Janken Myrdal har skrivit en bok om denna handskrift, just med titeln Den predikande räven. Arbete, skämt och allvar $i$ en medeltida illuminerad handskrift, Lund 2006.

13 Kerstin Rodin, Räven predikar för Gässen. En studie av ett ordspråk i senmedeltida ikonografi, Studia ethnologica 11, Stockholm 1983.

14 Rodin, s. 37. 


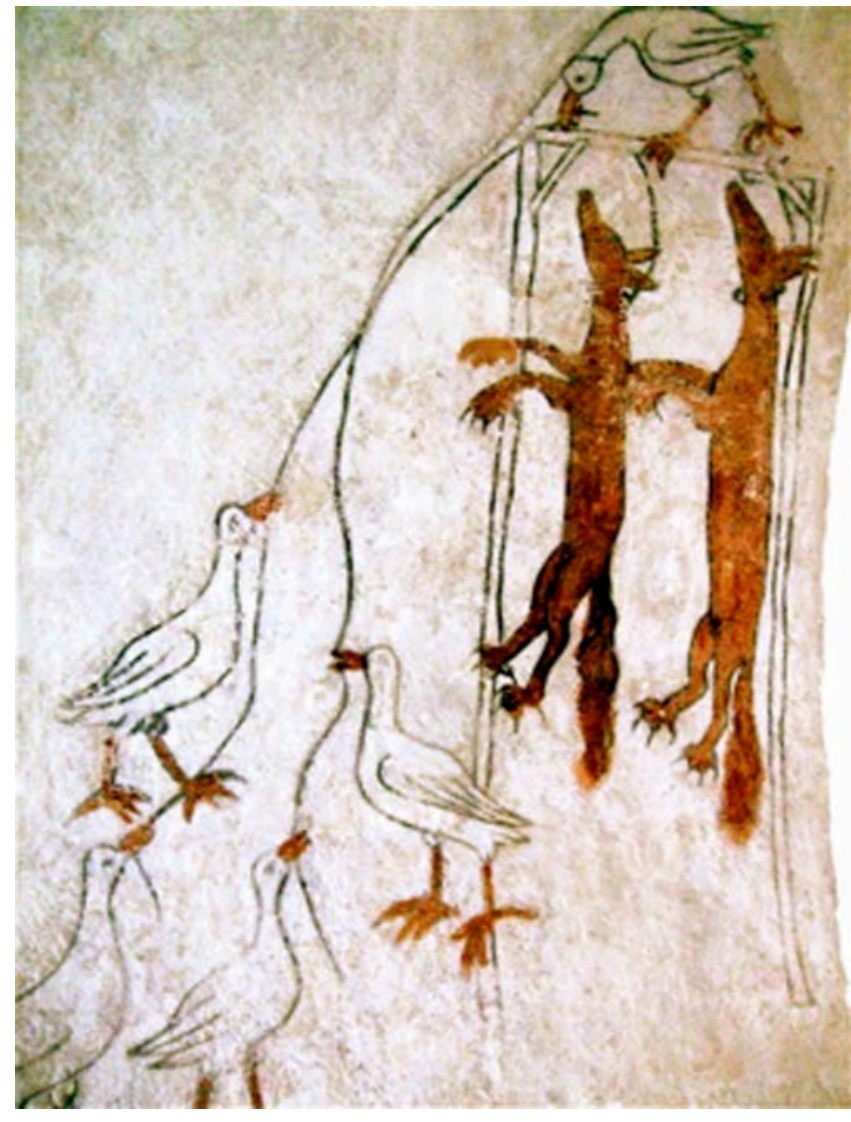

sin rättmätiga dom. De illistiga rävarna avrättas av gässen.

Den predikande räven förekommer inte som balladmotiv, men har naturligtvis nära släktskap med ballader som "Rävens testamente" och "Bonden och räven”. Mytbildningen kring räven som förknippad med ondska och list, likaså med det religiösa hyckleriet och skenheligheten, gör att vi lättare kan förstå "Rävens testamente", där räven räddar sitt skinn genom att vara skenhelig och att spela på bondens fromhet, liksom den hjälper oss att förstå att den sluge och försåtlige bonden i den andra rävballaden, ”Bonden och räven”, i själva verket är en hjälte när han dödar de båda rävarna, vilka helt enkelt kan ses som symboler för ondskan.

Haren som, olikt den listiga räven, ständigt flyr för varje fara och därför hör till de godsinta i djurmytologin, som om den oftast prekärt hotade haren i enlighet med Kristi rekommendation vore beredd att vända den andra kinden till, beständigt utsatt för hot som den är, själv aldrig angripare, dyker här och var upp både i balladerna och på den kyrkliga kalkmålningarna. Haren är den diametrala motsatsen till räven inom den medeltida djursymbolikens paradigm. Just därför måste Albertus Pictors målningar på temat "Söndagsjägaren” ha tett sig ytterst effektfulla och pedagogiskt omskakande. Det är en bildsvit av målningar som visar hur illa det

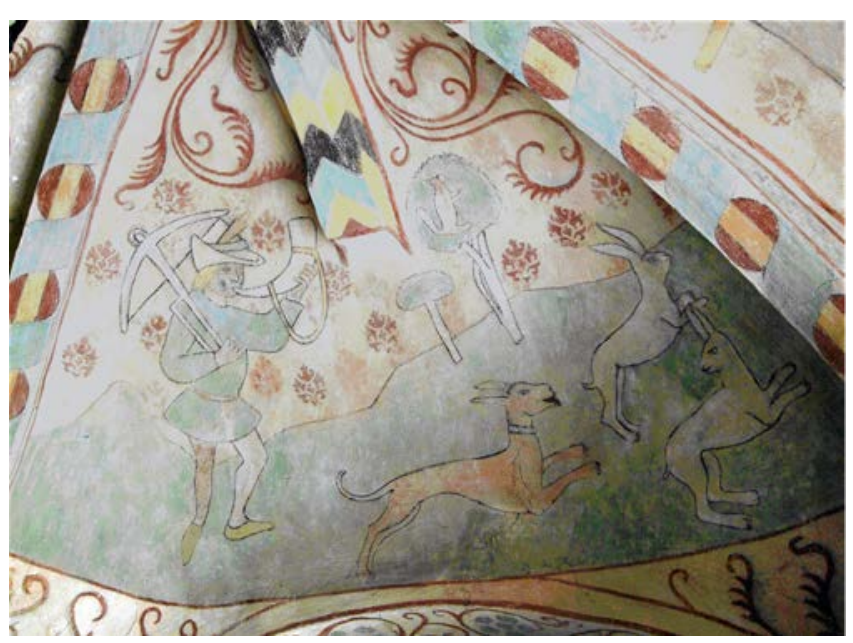
kan gå den som bryter mot det tredje av Guds bud, sabbatsbudet, detta att människan måste besinna sig och tänka på sin Skapare och vila på den sjunde dagen, på söndagen, den heliga sabbaten. På den första bilden i serien ger sig jägaren ut på jakt med sin hund, enligt Albertus Pictors bifogade språkband just på söndagen, syndigt nog. Hunden är domestiskt försedd med halsband; hussen blåser i sitt jakthorn.

Detta är en bildsvit i Kumla kyrka i Västmanland. Den fortsätter ganska omtumlande med att hararna på nästa bild har fångat jägaren och bundit upp honom på en stör som de 
bär mellan sig. Den syndige söndagsjägaren, han som bryter mot det tredje budet, blir alltså gruvligen straffad. Hans tilltänkta jaktoffer, de beskedliga och fega hararna, kan med Guds hjälp fånga in honom och bär honom på stören till sitt straff, nämligen att bli grillad. Överst återges en bild av hur hararna bär jägaren till grillen.

På den tredje och avslutande bilden i denna svit blir söndagsjägaren regelrätt grillad. Denna bildsvit i Kumla liknar en nutida tecknad serie och har en klart deklarerad sensmoral, som framgår av det språkband som Albertus har fogat till den tredje och sista bilden i denna lilla effektfullt tecknade serie. Där står det: "Om helga dagar du jagade fåglar och harar, derföre scal du nu til helvetet fara.” Det iscensätts så här, när jägaren grillas för att beredas till en läcker stek.
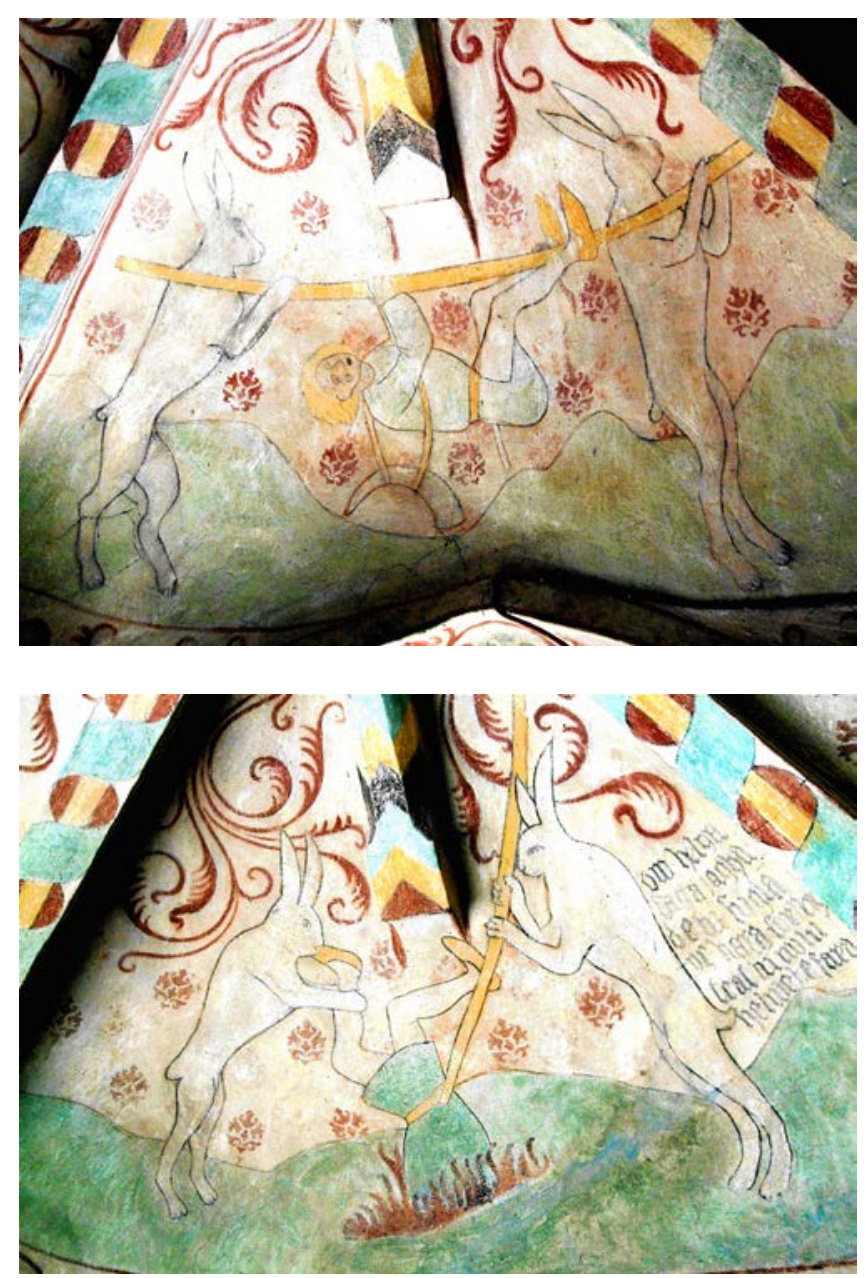
Man kan gissa att hararna i en situation som denna är beredda att göra ett avsteg från sin vegetarianism.

Sceneriet är balladeskt och kunde knappast tänkas utan ett metonymiskt ekorum i förbindelse med den medeltida balladens råbarkade sensibilitet och ganska högljudda mentala akustik, men till någon enskild nordisk skämtvisa kan man inte direkt knyta detta motiv. Dock är Albertus Pictors bildsvit mycket nära besläktad med balladen "Herr Nils och Herr Tideman", som ingick i Ingierd Gunnarsdotters repertoar. Det är en ballad som på danska heter "Helligbrøden" och av Grundtvig räknas som en legendvisa, medan den däremot överraskande nog och ytterst tvivelaktigt presenteras som en riddarvisa i såväl TSB som SMB. ${ }^{15}$ Balladen handlar om två bröder som ger sig ut för att jaga på en olämplig dag, hos Gunnarsdotter på "Midsomars morgon”, i den danska återgivningen ännu mer uppenbart förbjudet, nämligen på påskdagens morgon. Det straffar sig. Satan får snart korn på dem och ger sig in i den förbjudna leken:

Så rijda dhe lijtet bettre fram

igenom dee gröne hagar, för dem loph en lijten hind, de tänchte skulle warit en hare.

15 TSB D 299, SMB 146 A. 
För dem lopp en lijten hind, de mente skulle warit en haare, dhet war ey annadt ähn den lede Sathe som lekte för begges deres skade. ${ }^{16}$

Genom trolleriet med haren sår Satan split mellan bröderna, som börjar skryta för varandra och blir ovänner, så till den grad att de kommer av sig i sin jakt och i stället angriper varandra. De dödar varandra. Det är straffet:

Dhen ene fick sitt Bahne såhr

den andre blef slagen til Jorden ${ }^{17}$

Eftersom vi rör oss på jungfrulig mark, vill vi försöka undvika att extrapolera våra fynd och våra mer eller mindre nymorgnade iakttagelser, i varje fall nya inom forskningen kring nordiska kalkmålningar och deras relation till de medeltida balladerna, men trots detta vågar vi hävda att den medeltida kyrkliga bildkonsten har hämtat mycket inspiration från balladen och vice versa, i ett kommunikativt utbyte som på sin tid måste ha varit fullkomligt självklart och där subtila intermediala samband säkerligen ofta undgår oss utanförstående och sentida. Man anar, för att tala med 1920-talets surrealister, mängder av "kommunicerande kärl”, vases communicantes. Det är fråga om antika myter som spiller över i bibliska, även vice versa, och vi möter i våra skandinaviska kyrkor ibland norröna föreställningar hjälpligt extrapolerade till kristna. I medeltidens estetiskt kompilatoriska och smått karnevalsmässiga blandning av myter och konstnärliga manifestationer verkar nästan allt vara tillåtet, bara inte i närheten av altaret och det allra heligaste. Serenitet står i övrigt sida vid sida med vulgaritet; människan är dömd till syndafall och avstånd från Gud genom Evas allt förgörande förseelse att söka kunskap och äta ett äpple från det förbjudna trädet. Människan skulle vara hans avbild, hade Gud förutsagt, men när Eva tog för sig av Kunskapens träd kom hon för nära. Att människan skulle förstå skapelsens mening ingick inte i Guds plan. Evas tilltag ledde till Syndafallet och till människans successivt alltmer tynande kontakt med Gud.

Syndafallet fokuseras inom den kyrkliga bildkonsten i samma utsträckning som inom balladtraditionen och inom samtidens minst lika prosaiskt verklighetsorienterade som metafysiskt högtflygande teologi, åtminstone sådan denna manifesterade sig i den inom de påvliga domänerna under medeltiden nästan allt dominerande katolske filosofen Thomas ab Aquinos lika geniala som generöst utmätta världsbild, hängivet andlig och teologiskt sofistikerad, samtidigt rustikt folklig i sin framtoning. Thomas är snillet, den hyperbegåvade munken som är beredd att förklara allt och länka detta allt till Gud. Just hans beredskap att bejaka, att ta emot och vid behov försvara Guds alla manifestationer och deras verkningar, på sikt alltid till människans fromma, enligt hans uppfattning, gör att han försvarar humorn inom såväl kyrkomåleriet som i teologiska skrifter, tills han vid

16 SMB 146 A.

17 Ibid. För övrigt bör sägas att "Söndagsjägarna" har en pendang i Torshälla kyrka, även den av Albertus Pictor. Det är en bild av en kvinna som dansar på en söndag och därmed löser biljett till Helvetet. 
49 års ålder sätter ett streck i sitt författarskap och därefter under sin resterande levnad aldrig skriver en enda rad, en resolut tystnad som, utan jämförelse och konkurrens, är den europeiska idéhistoriens allra största gåta. Varför tystnade Thomas? ${ }^{18}$

Gick föreställningsvärldarna inte längre att jämka samman? Blev spänningen mellan heligt och profant för stort? Hos ingen medeltida tänkare förenas och tematiseras denna potentiella motsättning tydligare och med större energi än hos Thomas. Och ingen annanstans kvarstår denna motsättning så tydligt som i de medeltida kalkmålningarna, vare sig dessa har en direkt relation till den muntligt traderade balladerna eller om man måste nöja sig med att spåra närmevärden och mer eller mindre lösa förbindelser i ett ömsesidigt befrämjande kreativt samband.

Balladen "Herr Nils och Herr Tideman" har en tydlig affinitet med bildserien om "Söndagsjägaren" i Kumla kyrka i Västmanland, detta i kraft av det gemensamma temat. Men det finns, som vi tidigare har sett, mera omedelbara samband mellan ballader och kalkmålningar, helt enkelt målningar som är direkta återgivningar av centrala scener i balladerna. En sådan målning, lätt att identifiera och knyta till en bestämd ballad, är en dansk gestaltning i Sværdborgs kyrka av tvekampen mellan lejonet och lindormen. Bilden bygger på en gammal legendvisa, första gången publicerad och kommenterad i band 1 av Svend Grundtvigs Danmarks gamle folkeviser ${ }^{19}$ Det är en kämpavisa, känd sedan länge i Danmark, men någon svensk version av den finns inte, däremot en norsk. Den heter "Kong Diderik og Løven” på danska och börjar så här:

Dhett var her konyng Dhyryk, han skule tyl Berned ryde:

dher saa han dhen løve och dhen lynd-orm, saa ynkel mone dhe stryde.

Dhen lynd-orm han togen af. ${ }^{20}$

Så vill kungen hjälpa lejonet, "i-hor det ganger meg”, för att det i framtiden kan gagna honom, tänker han som en investering inför kommande bataljer, då lejonet kanske är villigt att stå honom bi, men hans svärd går itu när han försöker sticka det i lindormens hjärta och rädda lejonet, varpå lindormen under sin tunga bär både hästen och ryttaren till sitt bo, där nio hungriga lindormsungar fort äter upp hästen. Kungen får tills vidare sitta $i$ ett hörn, som fånge, medan lindormen sover en stund. Sedan finner den hjältemodige kungen på list och hugger ihjäl lindormen och alla hennes ungar, lurar till sig en nyckel och flyr ur grottan. Någon kung ser vi inte på bilden i Sværdborgs kyrka, men vad vi ser är den scen som lockade kung Didrik till hjältedater, nämligen tvekampen mellan lejonet och lindormen, den som Didrik ingrep i, till en början med magert resultat, men sedan, efter viss spänning, i stor triumf på slutet:

18 Stewe Claeson har skrivit en roman om denna gåta, Halm, Stehag 2000. Titeln är hämtad från Thomas' besked till sitt skrivbiträde, att allt han hade skrivit var "halm” och att han därför satte punkt för gott. Så blev det också, inte en rad mer. Thomas levde ytterligare drygt ett år.

19 Svend Grundtvig (utg.), Danmarks gamle folkeviser, band I, Kjöbenhavn 1853, ss. 129-153.

20 Dgf 9 A. 


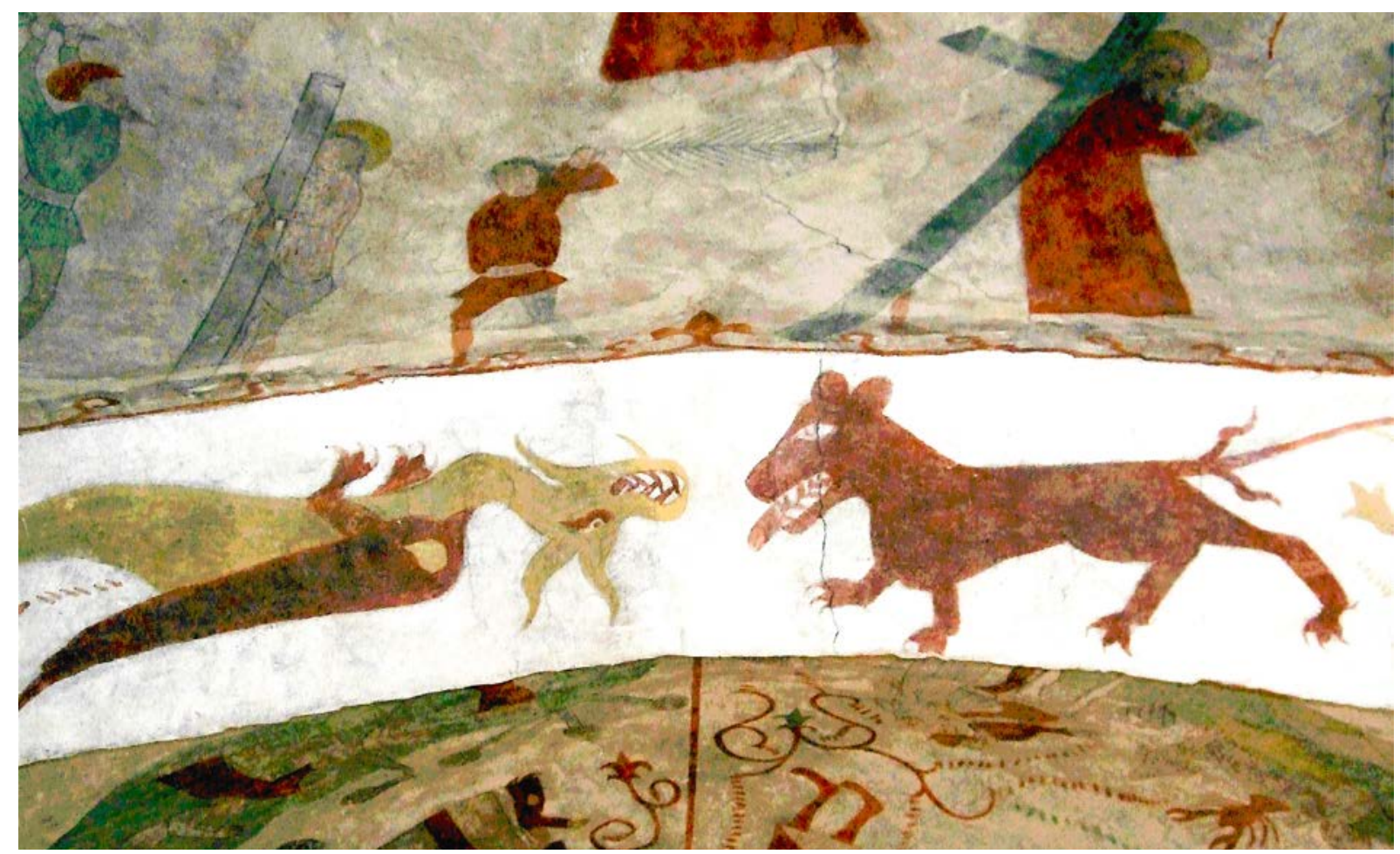

Djur pockar på sin innebördsmättade symboliska närvaro i många ballader, naturligt nog främst i skämtvisorna. Vi gav inledningsvis några exempel, men vi har naturligtvis fler i vår medeltida balladskatt, till exempel "Kolorumgris" (SMB 249) om en urbota mansgris med en "arschelring" som är "femton alnar omkring", även "Bonden och oxen" (SMB 255) som behandlar dåtidens skoningslösa klassamhälle i humoristiskt överslätande ordalag, utmynnande i en maning till förnöjsamhet, en skämtvisa som alltså är långt ifrån subversiv utan konservativt bejakande av ett feodalt status quo och en gammaltestamentligt förtryckande könsordning.

En särställning intar de bilder som uppvisar musicerande djur. De har ingen identifier-

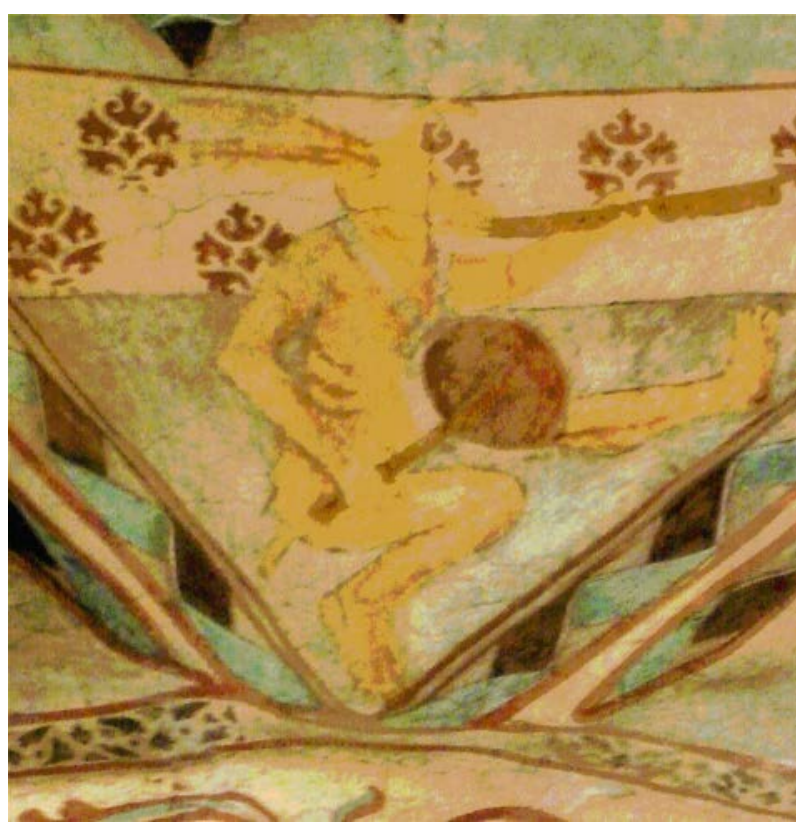
bar anknytning till den medeltida balladen, i varje fall inte direkt, så att man kan säga att de utgör ett visualiserat eko av den eller den balladen. Någonstans finner vi bilden av en gris som spelar orgel, en kaninkör som sjunger, en åsna som med rumpan blåser i en flöjt. Direkt motsvarande ballader? Nej. Men finns det besläktade motiv i balladerna? Ja, tveklöst, utan exakt kongruens, men samma andas barn. Det är en bild av Albertus Pictor, i Floda kyrka, av en gulmenad kanin som ser ut att spela flöjt och samtidigt traktera ett slaginstrument, inte olikt en stekpanna. 
Denna kanin är mest skrattretande och absurd, säkerligen menad att te sig just sådan, men han har djuriska musikerkolleger som inte verkar vara avsedda att te sig lika tokiga. Ett förtroendeingivande exempel är vildsvinet som spelar på luta, omgiven av bibliska bilder i Vrås kyrka på Jylland.

Ett vildsvin som spelar fram scener ur den bibliska historien, kan närheten mellan det teologiska och det balladeska manifesteras tydligare än så? Vildsvinet som spelar på sin luta och sjunger om Kristi lidande, om Yttersta domen och andra viktiga kristna begivenheter är en övertygande och väl närmast emblematisk sinnebild för den kristna föreställningsvärldens intima samröre med balladens värld, sådan denna kan gestaltas på målningar i medeltida kyrkor. Till höger ser vi i närbild vildsvinet som spelar luta.

Vildsvinet som spelar luta är ett tacksamt och belysande exempel hämtat från den medeltida bildvärlden. Denne musikant kan inte utan överdriven ansträngning knytas till någon bestämd ballad, även om sådana kandidater till nöds förvisso finns, men enligt vår mening är han framför allt just en balladesk gestalt, en balladesk grisgestalt i allmänhet, som sådan uppenbarligen i
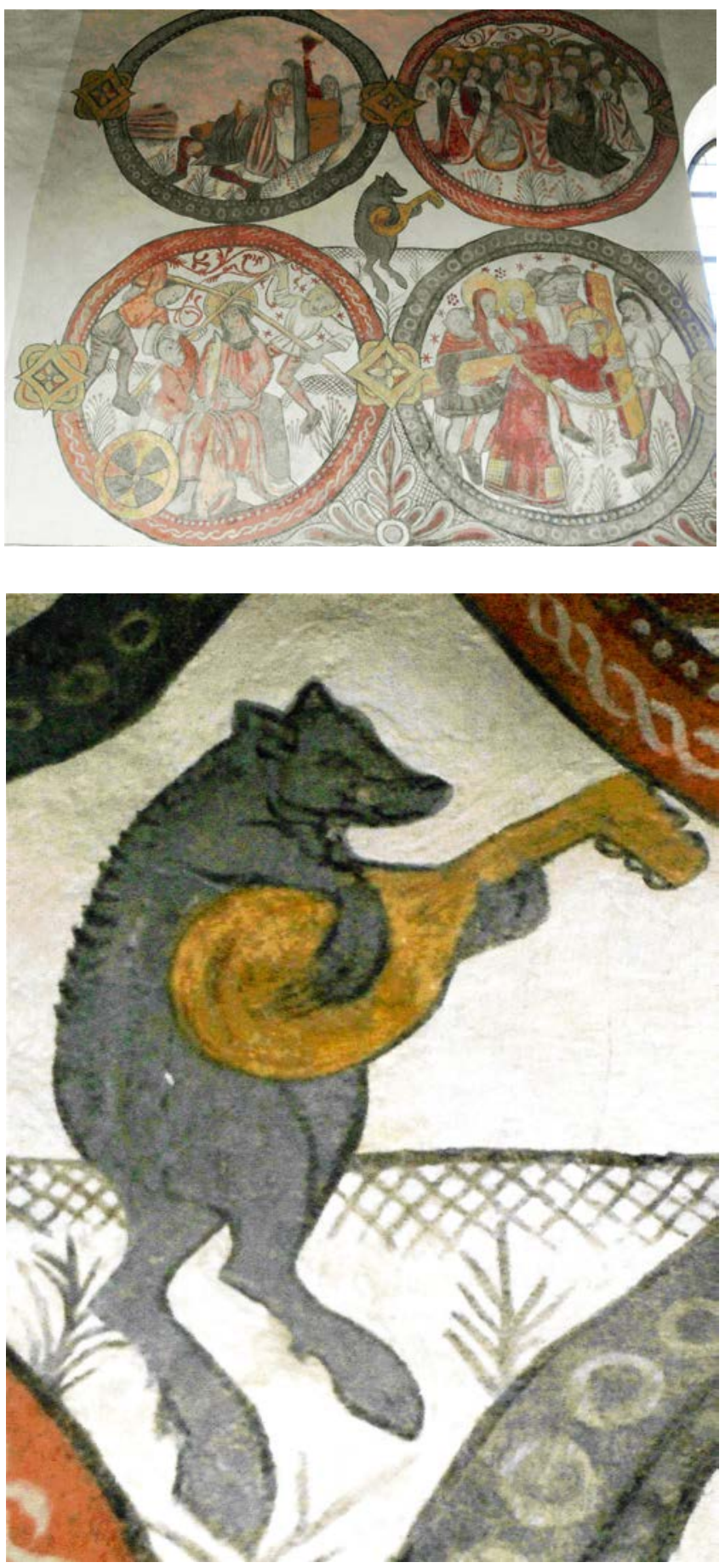
färd med att framföra en visa - och omöjlig att tänka sig utan det samröre med de medeltida balladernas värld som de gamla kyrkmålningarna mer eller mindre tydligt uppvisar.

Det lutspelande svinet är en balladfigur och tillhör skämtvisans skrattretande föreställningsvärld, vare sig vi lyckas finna balladen om denna musicerande gris eller inte. Den finns kanske inte, längre, har kanske aldrig funnits, men vildsvinet som spelar luta är alldeles otänkbart utan denna kulturhistoriska kontext.

Mycket mer finns att säga om djurmotiven i balladerna och på kalkmålningarna, men här syftar vi inte till någon uttömmande redovisning utan till att dryfta och visa det mest originella och tankeväckande. Det är nu gjort. 